\title{
Mild hyperthermia predisposes tumor cells to undergo apoptosis upon treatment with onconase
}

\author{
H. DOROTA HALICKA ${ }^{1}$, BARBARA ARDELT ${ }^{2}$, KUSLIMA SHOGEN $^{2}$ and ZBIGNIEW DARZYNKIEWICZ ${ }^{1}$ \\ ${ }^{1}$ Brander Cancer Research Institute and Department of Pathology, New York Medical College, Valhalla, \\ NY 10595; ${ }^{2}$ Alfacell Research Laboratories, 225 Belleville Avenue, Bloomfield, NJ 07003, USA
}

Received November 17, 2006; Accepted December 28, 2006

\begin{abstract}
Onconase (ONC), (ranpirnase) a cytotoxic ribonuclease isolated from amphibian oocytes and early embryos targeting tumor cells in vitro and in vivo, is currently in a confirmatory Phase IIIb clinical trial for unresectable malignant mesothelioma where it demonstrates antitumor activity with relatively minor overall toxicity to patients. Since hyperthermia has been shown to be synergistic with certain antitumor modalities, the aim of the present study was to explore whether the cytotoxic effects of ONC can be enhanced under conditions of mild hyperthermia. Treatment of human lymphoblastoid TK6 cells with 2 or $5 \mu \mathrm{g} / \mathrm{ml}$ of ONC at $40^{\circ} \mathrm{C}$ for 24 or $48 \mathrm{~h}$ led to $64-200 \%$ enhancement in incidence of apoptosis assessed by frequency of cells showing the presence of activated (cleaved) caspase- 3 or activated serine proteases, compared to treatment at $37.5^{\circ} \mathrm{C}$. The incidence of apoptosis at $40^{\circ} \mathrm{C}$ in the absence of $\mathrm{ONC}$ was unchanged compared to $37.5^{\circ} \mathrm{C}$, for up to $48 \mathrm{~h}$. Although at $41^{\circ} \mathrm{C}$ in absence of ONC the incidence of apoptosis was elevated compared to $37^{\circ} \mathrm{C}$ the cytotoxicity of ONC was further enhanced and the overall pro-apoptotic effect was above the level of additive effects of ONC plus that of $41^{\circ} \mathrm{C}$-hyperthermia. While the mechanism of the observed enhancement of ONC cytotoxicity is currently under investigation, the findings suggest that a combination of ONC and mild hyperthermia should be explored to increase effectiveness of ONC in cancer treatment.
\end{abstract}

\section{Introduction}

Onconase (ONC) (ranpirnase) is a germ plasm ribonuclease isolated from oocytes or early embryos of Northern Leopard frog (Rana pipiens) (1-3). This protein is the smallest member $(\sim 12,000 \mathrm{MW})$ of pancreatic RNase A superfamily and it displays weak ribonucleolytic activity (reviewed in refs. 4-8).

Correspondence to: Professor Z. Darzynkiewicz, Brander Cancer Research Institute, New York Medical College, Valhalla, NY 10595, USA

E-mail: darzynk@nymc.edu

Key words: ranpirnase, cytotoxic RNase, apoptosis, caspase-3 activation, TK6 cells, mesothelioma, RNA interference, microRNAs
ONC suppresses proliferation and is cytotoxic to several tumor cell lines of different lineage (9-15). It also inhibits growth of certain tumors in mice (16) and is synergistic with many chemotherapeutic agents $(11,13,15-18)$. ONC is currently in Phase IIIb confirmatory clinical trial for unresectable malignant mesothelioma (UMM) where it demonstrates antitumor activity with relatively minor overall toxicity to the patient $(4,19)$.

The cytostatic effect of ONC, seen after $24 \mathrm{~h}$ of the treatment, manifests as an arrest in $\mathrm{G}_{0 / 1}$ phase of the cell cycle and is followed by apoptosis during which caspases and serine proteases are being activated $(9,16,20-22)$. The $\mathrm{G}_{0 / 1}$ arrest of histiomonocytic lymphoma U-937 cells was shown to be mediated by downregulation of cyclin D3, upregulation of the inhibitors of cyclin-dependent kinases (CKIs) p2 $7^{\mathrm{KIP} 1}$, $\mathrm{p} 16^{\mathrm{INK} 4 \mathrm{~A}}$ and $\mathrm{p} 21^{\mathrm{WAF} 1 / \mathrm{CIP1}}$ and hypophosphorylation of pRb (20). It is unknown whether this mechanism of cytostasis induced by ONC is generic, common to other cell types, or only to U-937 cells.

ONC binds to receptors on plasma membrane of the sensitive cells and is internalized by a dynamin-independent endocytic pathway $(14,23,24)$. The ribonucleolytic activity of ONC is essential for its cytostatic and cytotoxic effects, and it was reported that within the target cells tRNA was preferentially degraded $(14,26)$. It has been postulated, therefore, that these effects of ONC are mediated by degradation of intracellular tRNA which leads to overall suppression of the rate of protein synthesis $(14,25,26)$.

Several observations, however, cannot be explained by such a mechanism. The upregulation of CKIs by ONC (20), for example, would be incompatible with the mechanism based on indiscriminate suppression of translation by this drug. Furthermore, suppression of protein synthesis appears to play no role in induction of apoptosis by ONC (25). Also, the patterns of cytostatic and cytotoxic effects of ONC on different cell types are quite different compared to the effects of classic inhibitors of transcription or translation such as actinomycin D or cycloheximide $(27,28)$. All these observations suggest that tRNA cannot be the sole target of ONC. We proposed, therefore, that at least in part, ONC may exert its effects by targeting RNAs that play a role in regulation of the translation (siRNA, miRNA, microRNAs) by the RNA interference (RNAi) mechanism (29). It is intriguing that this protein, repeatedly infused during treatment of patients, has no significant immunogenic activity $(5,19)$. Perhaps the enhancement of activation-induced apoptosis of lymphocytes 
by ONC may be responsible for the suppression of immunogenic response (30).

Hyperthermia alone has been used to treat some forms of cancer (reviewed in ref. 31). More frequently, however, hyperthermia is being combined with chemo- or radiotherapy. Depending on the nature of the chemotherapeutic agent and tumor type the antitumor effect of such combinations varies, but often is enhanced in comparison to the effect of chemotherapeutic agents alone (31-38). The aim of the present study was to explore whether the cytotoxic effect of ONC can be enhanced under condition of mild hyperthermia, when thermal effects on cells viability are either not detectable or minor. Towards this aim we tested the effect of hyperthermia on the potency of ONC to induce apoptosis of human lymphoblastoid TK6 cells.

\section{Materials and methods}

Cells and culture conditions. Human B cell lymphoblastoid TK6 cells were kindly provided by Dr Howard Liber of Colorado State University, Fort Collins Co. (39). The cells were grown in $25 \mathrm{ml}$ Falcon flasks (Becton Dickinson Co., Franklin Lakes, NJ) in RPMI-1640 supplemented with 10\% fetal calf serum, 100 units $/ \mathrm{ml}$ penicillin, $100 \mu \mathrm{g} / \mathrm{ml}$ streptomycin and $2 \mathrm{mM}$ L-glutamine (all from Gibco/BRL Life Technologies, Inc., Grand Island, NY) at $37.5,40$ or $41^{\circ} \mathrm{C}$ in an atmosphere of $5 \% \mathrm{CO}_{2}$ in air, as described in the figure legends. ONC (Alfacell Corp., Bloomfield, NJ) was dissolved in phosphate-buffered saline (PBS) at concentration of $1 \mathrm{mg} / \mathrm{ml}$ to obtain stock solution, which was freshly made. Some cultures were treated with a stock solution of ONC to obtain final ONC concentrations 2 or $5 \mu \mathrm{g} / \mathrm{ml}$; parallel control cultures were treated with equivalent volumes of PBS. At the onset of the experiments, there were $\sim 2 \times 10^{5}$ cells per $\mathrm{ml}$ in cultures and the cells were at an exponential and asynchronous phase of growth. The cultures were consistently screened for possible contamination with Mycoplasma microorganisms. Other details of cell culturing are presented elsewhere (40).

Detection of caspase-3 activation and apoptosis by fluorescence microscopy. Cells grown in the absence or presence of ONC at different temperatures were rinsed with PBS and then fixed in $1 \%$ methanol-free formaldehyde in PBS (on ice, $15 \mathrm{~min}$ ) followed by $70 \%$ ethanol at $4^{\circ} \mathrm{C}$. After being washed with PBS, the cells were immersed in $0.2 \%$ Triton X-100 (Sigma Chemical Co., St. Louis, MO) in a $1 \%(\mathrm{w} / \mathrm{v})$ bovine serum albumin (BSA) solution in PBS for $30 \mathrm{~min}$. The cells were then incubated in $100 \mu 1$ of $1 \%$ BSA containing 1:100 diluted anti-cleaved (activated) caspase-3 rabbit polyclonal Ab (Cell Signaling Technology, Beverly, MA) overnight at $4^{\circ} \mathrm{C}$, washed twice with PBS and then incubated in $100 \mu \mathrm{l}$ of 1:200 diluted Alexa Fluor ${ }^{\circledR} 488$ conjugated goat anti-rabbit IgG (H+L) (Invitrogen/Molecular Probes, Carlsbad, CA) for $30 \mathrm{~min}$ in room temperature in the dark. The cells were then counter-stained either with $10 \mu \mathrm{g} / \mathrm{ml}$ of propidium iodide (PI; Invitrogen/Molecular Probes) in the presence of $100 \mu \mathrm{g}$ of RNase A (Sigma) for $30 \mathrm{~min}$ for analysis by flow cytometry, or with $1 \mu \mathrm{g} / \mathrm{ml}$ of 4',6-diamidino-2-phenylindole (DAPI) and $10 \mu \mathrm{g} / \mathrm{ml}$ of sulforhodamine 101 in PBS for
5 min for inspection by fluorescence microscopy. Cellular morphology and fluorescence was examined under a Nikon Microphot FXA microscope, utilizing a 40X objective.

Detection of serine protease(s) activation. An unprotected analog of the serine protease inhibitor, N-tosyl-L-phenylalanine chloromethylketone (TPCK; TFCK using current amino-acid symbols) has been modified to obtain 5(6)-carboxyfluoresceinyl-L-phenylalanylchloromethyl ketone (FFCK); the chymotrypsin-like serine protease active center ligand that contains the fluorescent tag $(41,42)$. This reagent was obtained from Immunochemistry Technologies (Bloomington, $\mathrm{MN}$ ) as part of a 2-color (dual label) caspase-serine protease detection kit. The reagent stored in the dark at $-80^{\circ} \mathrm{C}$ was dissolved initially in DMSO to yield a $50 \mathrm{mM}$ concentration. Aliquots were then made from this stock solution and stored frozen at $-20^{\circ} \mathrm{C}$ protected from light. An additional dilution in DMSO was made to get the FFCK reagent down to $10 \mathrm{mM}$ concentration prior to its use for cell labeling. FFCK was then included into culture medium at $10 \mu \mathrm{M}$ final concentration and the cells were incubated in its presence for $30 \mathrm{~min}$ at $37^{\circ} \mathrm{C}$; PI was added for the final $5 \mathrm{~min}$ of incubation. Dilution of the reagent into aqueous (cell culture) media was done just prior to cell exposure to preserve the labile chloromethyl ketone reactivity of FFCK reagent. Other details of serine protease labeling with FFCK are presented elsewhere $(41,42)$.

Flow cytometry. Cellular green (Alexa Fluor 488), or FFCK, and red (PI) fluorescence emission was measured using either a FASCcan (Becton-Dickinson, San Jose, CA), or EPICS/ Elite (Coulter-Beckman, Miami, FL) flow cytometers, each employing $488 \mathrm{~nm}$ laser as excitation source. The green and red fluorescence from each cell were separated and quantified using the standard optics and CELLQuest (Becton-Dickinson) or MultiCycle (Phoenix Flow Systems, San Diego, CA) software, respectively. Cells $(10,000)$ were measured per each sample. Each experiment was run in duplicate and the experiments were repeated at least twice. Other details of the fluorochrome-cell labeling and flow cytometric analysis were presented before (40-44).

\section{Results}

Fig. 1 shows morphological appearance of cells growing in the absence or presence of $2 \mu \mathrm{g} / \mathrm{ml}$ of $\mathrm{ONC}$ at 37.5 or $40^{\circ} \mathrm{C}$ for $24 \mathrm{~h}$. Cell growth at $40^{\circ} \mathrm{C}$ in the absence of $\mathrm{ONC}$ had no apparent effect on their morphology and did not significantly suppress their proliferation, as evident from the presence of mitotic figures (Fig. 1B). Exposure of cells to ONC at $37.5^{\circ} \mathrm{C}$ led to the appearance of relatively few apoptotic cells characterized by cell shrinkage, highly condensed chromatin and nuclear fragmentation (Fig. 1C, arrows). The frequency of apoptotic cells was distinctly higher in cultures containing ONC but maintained at $40^{\circ} \mathrm{C}$ compared to cultures treated with $\mathrm{ONC}$ at $37.5^{\circ} \mathrm{C}$ (Fig. 1D). The cells characterized by morphological changes typical of apoptosis expressed activated caspase-3 (Fig. 2).

Fig. 3 illustrates effects of $\mathrm{ONC}$ alone, $40^{\circ} \mathrm{C}$-hyperthermia and combined effects of $\mathrm{ONC}$ and hyperthermia on induction of apoptosis of TK6 cells after $24 \mathrm{~h}$ of the treatment. The 

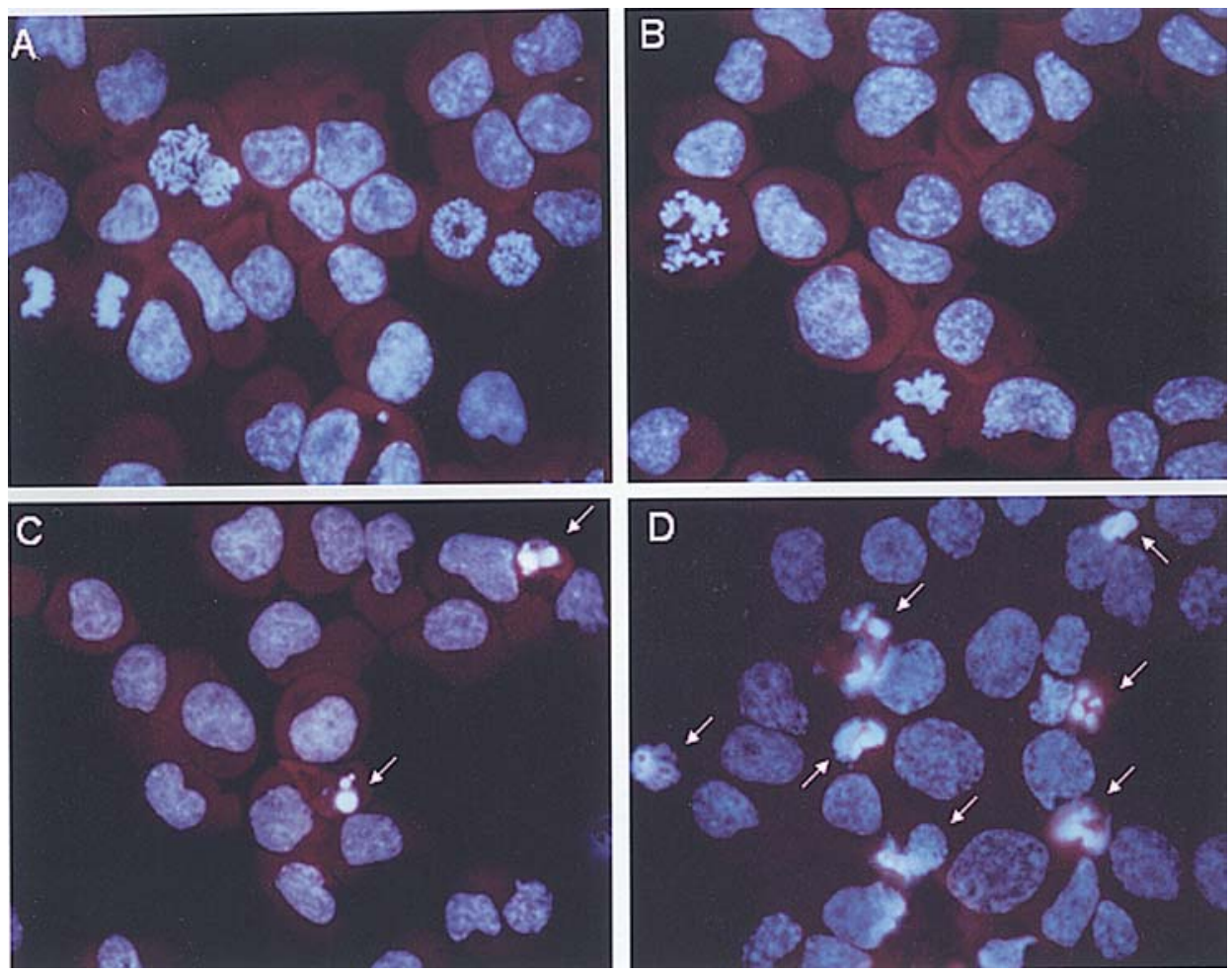

Figure 1. Morphology of TK6 cells, growing at $37.5^{\circ} \mathrm{C}(\mathrm{A})$, at $40^{\circ} \mathrm{C}(\mathrm{B})$, treated with $2 \mu \mathrm{g} / \mathrm{ml}$ of ONC at $37^{\circ} \mathrm{C}(\mathrm{C})$ and treated with $2 \mu \mathrm{g} / \mathrm{ml}$ of $\mathrm{ONC}$ at $40^{\circ} \mathrm{C}$ (D). The cells were maintained in culture at 37.5 or $40^{\circ} \mathrm{C}$ without or with $\mathrm{ONC}$ for $24 \mathrm{~h}$ then were deposited on slides by cytocentrifugation, fixed, stained with DAPI and sulforhodamine 101 and examined by fluorescence microscopy as described (46). Note characteristic cell shrinkage, chromatin condensation and nuclear fragmentation of apoptotic cells (marked by arrows).
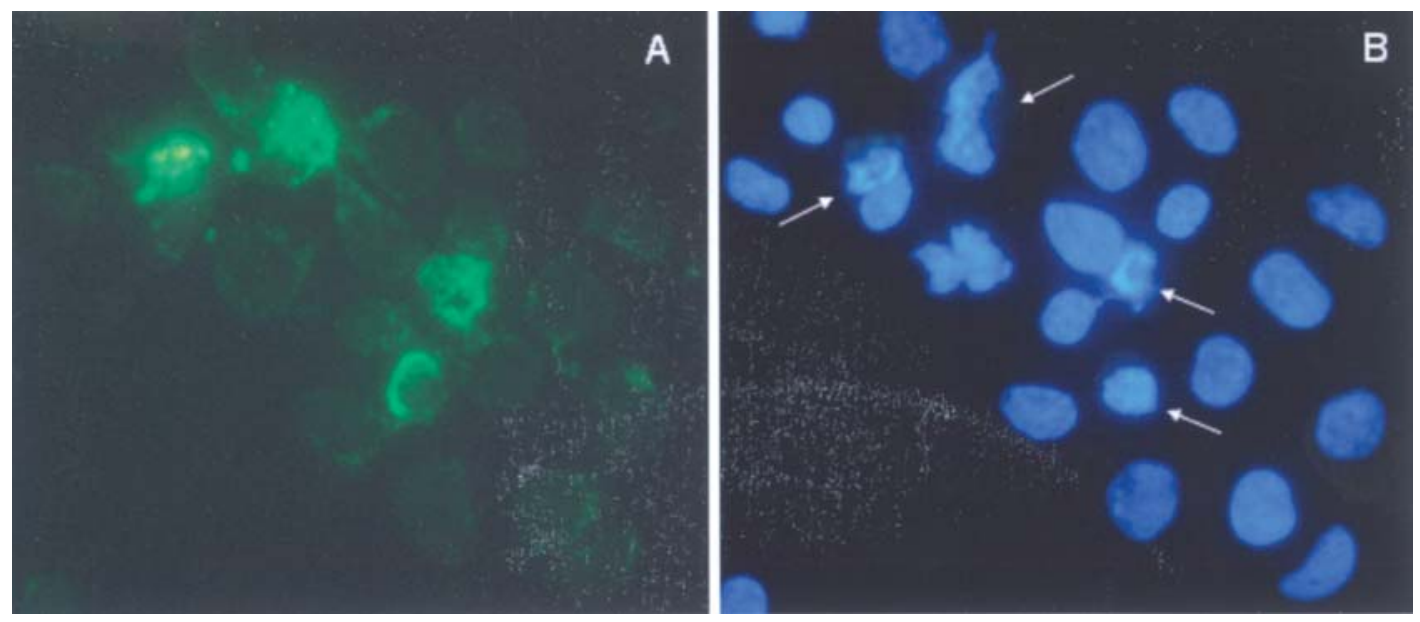

Figure 2. Activation of caspase-3 in TK6 cells grown at $40^{\circ} \mathrm{C}$ in the presence of $2 \mu \mathrm{g} / \mathrm{ml}$ of ONC for $24 \mathrm{~h}$. The cells were deposited on slides by cytocentrifugation, fixed and the presence of activated (cleaved) capase- 3 was detected immunocytochemically using Alexa Fluor ${ }^{\circledR} 488$ conjugated secondary $\mathrm{Ab}(\mathrm{A})$; cellular DNA was counterstained with DAPI (B). Note that apoptotic cells characterized by condensed chromatin (B, arrows) express activated caspase-3.

data are shown as scatterplots representing individual cells expressing activated caspase- 3 vs. DNA content, measured by flow cytometry. It is quite evident that cell growth at $40^{\circ} \mathrm{C}$ in the absence of ONC did not lead to any increase in the percentage of apoptotic cells as compared to $37.5^{\circ} \mathrm{C}$. The presence of minor subpopulation (6\%) of cells expressing activated caspase- 3 at 37.5 and $40^{\circ} \mathrm{C}$ reflects the background level of spontaneous apoptosis observed in cultures of TK6 cells (40). A modest increase in percentage of apoptotic cells (to 13 or $15 \%$, respectively) was apparent in cultures treated with 2 or $5 \mu \mathrm{g} / \mathrm{ml}$ of $\mathrm{ONC}$ at $37.5^{\circ} \mathrm{C}$. However, in cultures treated with 2 or $5 \mu \mathrm{g} / \mathrm{ml}$ of $\mathrm{ONC}$ at $40^{\circ} \mathrm{C}$ the percent of apoptotic cells was increased to 39 and $49 \%$, respectively, well above the level seen in the cultures treated with $\mathrm{ONC}$ at $37^{\circ} \mathrm{C}$.

The percentage of cells with activated caspase- 3 in cultures exposed to ONC at 37.5 and $40^{\circ} \mathrm{C}$ for the duration of 24 or 

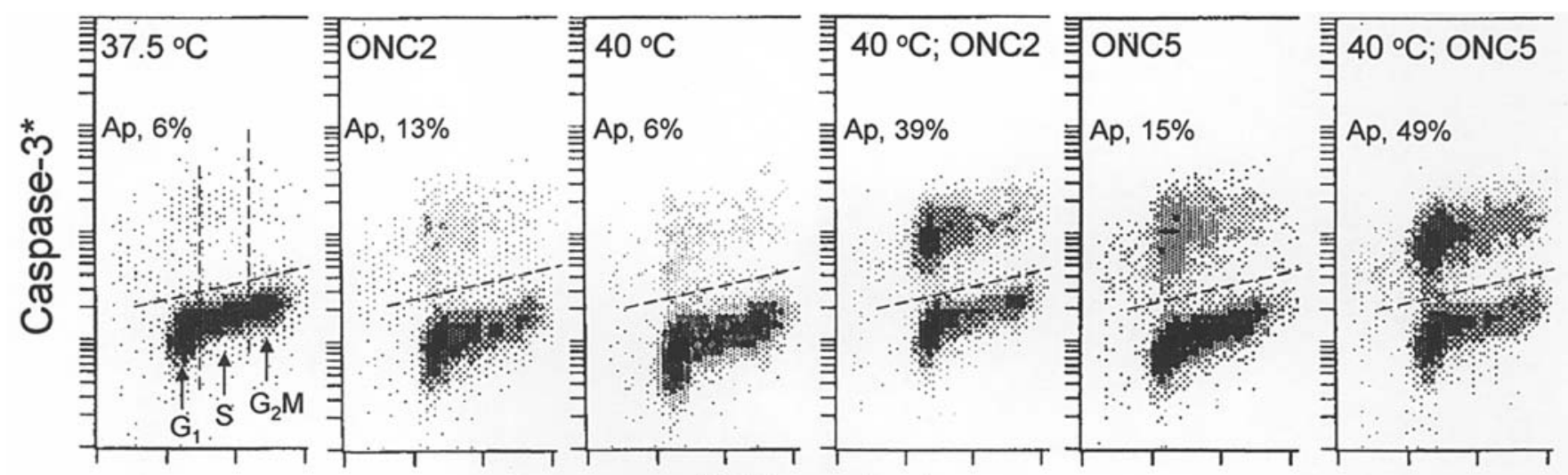

DNA content

Figure 3. Induction of apoptosis of TK6 cells by ONC in cultures maintained at 37.5 and $40^{\circ} \mathrm{C}$ for $24 \mathrm{~h}$. Bivariate distributions (scatterplots) showing cellular DNA content vs. the presence of activated (cleaved) caspase-3 detected immunocytochemically of the untreated cells growing at $37.5^{\circ} \mathrm{C}\left(37.5^{\circ} \mathrm{C}\right)$, treated with 2 or $5 \mu \mathrm{g} / \mathrm{ml}$ of ONC at $37.5^{\circ} \mathrm{C}$ (ONC2, ONC5, respectively) or treated with 2 or $5 \mu \mathrm{g} / \mathrm{ml}$ of ONC at $40^{\circ} \mathrm{C}\left(40^{\circ} \mathrm{C}, \mathrm{ONC} 2 ; 40^{\circ} \mathrm{C}\right.$, ONC5; respectively). The percent of apoptotic cells (Ap) expressing activated caspase-3 (above the threshold is marked with a dashed line) is shown in each panel.

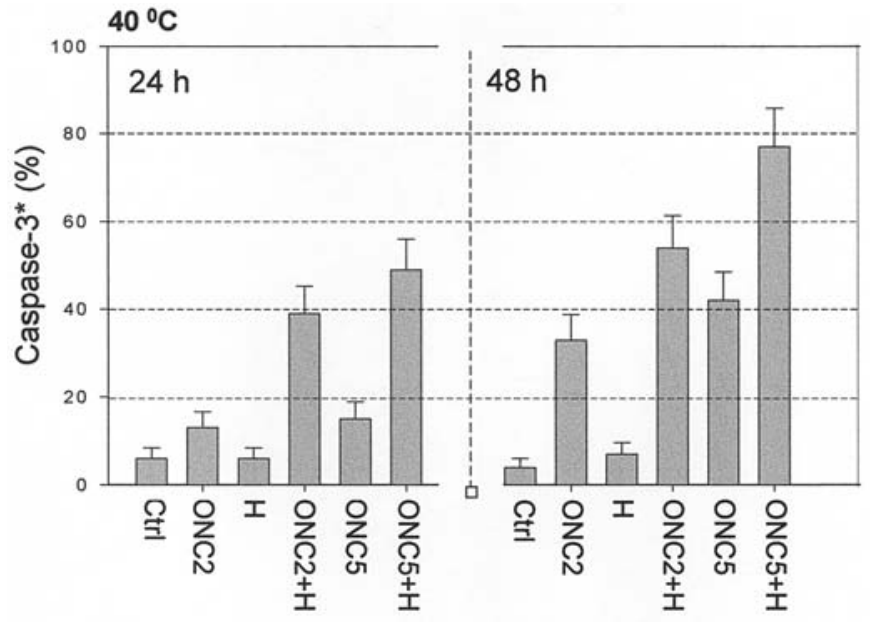

Figure 4. Induction of apoptosis of TK6 cells by ONC in cultures maintained at 37.5 and $40^{\circ} \mathrm{C}$ for 24 or $48 \mathrm{~h}$. The bars show percentage of cells expressing activated caspase- 3 following growth at $37.5^{\circ} \mathrm{C}$ in the absence of ONC (Ctrl), at $37.5^{\circ} \mathrm{C}$ in the presence of 2 or $5 \mu \mathrm{g} / \mathrm{ml}$ of ONC (ONC2 or ONC5, respectively) or grown at $40^{\circ} \mathrm{C}$ in the absence $(\mathrm{H})$ or presence of 2 or $5 \mu \mathrm{g} / \mathrm{ml}$ of $\mathrm{ONC}(\mathrm{ONC} 2+\mathrm{H}$ or $\mathrm{ONC} 5+\mathrm{H}$, respectively). The bars show $\mathrm{SD}$ estimated based on Poisson statistical distribution.

$48 \mathrm{~h}$ is shown in Fig. 4 as bar graphs. The bars representing cells after $24 \mathrm{~h}$ of the treatment report the raw data illustrated in Fig. 3. Compared to cells treated for $24 \mathrm{~h}$ the cytotoxic effects observed after $48 \mathrm{~h}$ of exposure to ONC were more pronounced. Thus, at $37.5^{\circ} \mathrm{C}$ apoptotic cells were present at a higher frequency after $48 \mathrm{~h}$ than after $24 \mathrm{~h}$. This was apparent both at 2 and $5 \mu \mathrm{g} / \mathrm{ml}$ concentration of ONC (33 and $42 \%$ vs. 13 and $15 \%$, respectively). In contrast, cell growth at $40^{\circ} \mathrm{C}$ in the absence of ONC for $48 \mathrm{~h}$ did not lead to any further increase in percentage of apoptotic cells compared to $24 \mathrm{~h}$ (7 vs. $6 \%$ ). In the presence of 2 or $5 \mu \mathrm{g} / \mathrm{ml}$ of $\mathrm{ONC}$ at $40^{\circ} \mathrm{C}$, however, the percentage of apoptotic cells was distinctly higher after $48 \mathrm{~h}$ than after $24 \mathrm{~h} \mathrm{(54}$ and $77 \%$ vs. 39 and $49 \%$, respectively).

Fig. 5 shows the results of the experiment designed as the one presented in Fig. 3 but carried out at $41^{\circ} \mathrm{C}$ rather than at

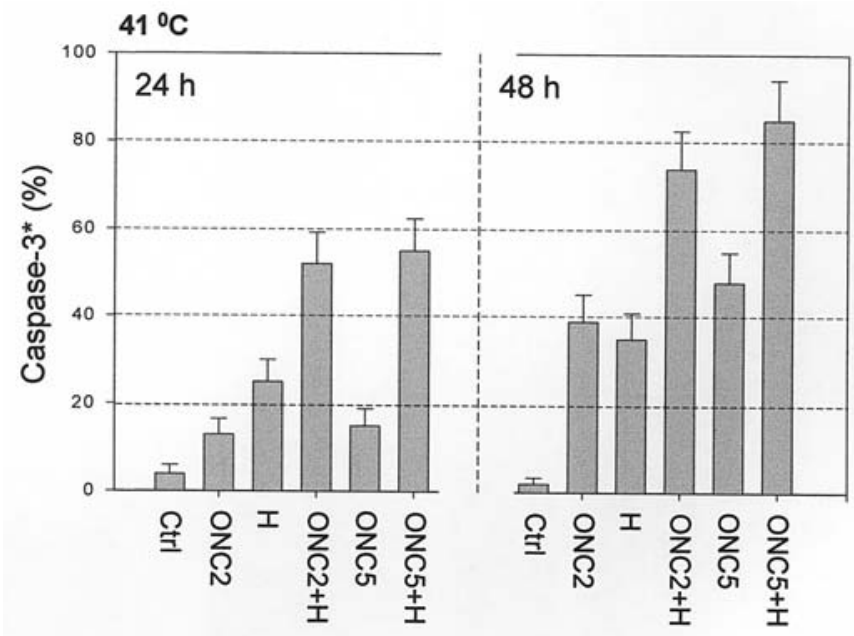

Figure 5. Induction of apoptosis of TK6 cells by ONC in cultures maintained at 37.5 and $41^{\circ} \mathrm{C}$ for 24 or $48 \mathrm{~h}$. The bars show percentage of cells expressing activated caspase- 3 following growth at $37.5^{\circ} \mathrm{C}$ in the absence of ONC (Ctrl), at $37.5^{\circ} \mathrm{C}$ in the presence of 2 or $5 \mu \mathrm{g} / \mathrm{ml}$ of ONC (ONC2 or ONC5, respectively) or grown at $41^{\circ} \mathrm{C}$ in the absence $(\mathrm{H})$ or presence of 2 or $5 \mu \mathrm{g} /$ $\mathrm{ml}$ of ONC $(\mathrm{ONC} 2+\mathrm{H}$ or ONC $5+\mathrm{H}$, respectively). The bars show SD estimated based on Poisson statistical distribution.

$40^{\circ} \mathrm{C}$. It is quite evident that unlike $40^{\circ} \mathrm{C}$, the $41^{\circ} \mathrm{C}$-hyperthermia itself was cytotoxic, inducing apoptosis of 25 and $45 \%$ of cells after 24 and $48 \mathrm{~h}$, respectively. Similar as at $40^{\circ} \mathrm{C}$, however, the effects of treatment of cells with $\mathrm{ONC}$ at $41^{\circ} \mathrm{C}$ after $24 \mathrm{~h}$ were greater than additive. After $48 \mathrm{~h}$ of treatment with 2 or $5 \mu \mathrm{g} / \mathrm{ml}$ of $\mathrm{ONC}$ at $41^{\circ} \mathrm{C}$ a large majority of cells ( 74 or $85 \%$ cells) expressed activated caspase- 3 .

We observed before that during the ONC-induced apoptosis of HL-60 cells serine proteases were activated concurrently with activation of caspases (21). In the present study, therefore, we tested whether apoptosis induced by a combination of ONC and mild hyperthermia can also lead to activation of serine proteases. As before (21), the probe (FFCK) used to detect serine proteases activation was a fluorochrome-tagged analog of TPCK (TFCK according to the current amino-acid abbreviations), the permeant and specific ligand-inhibitor 


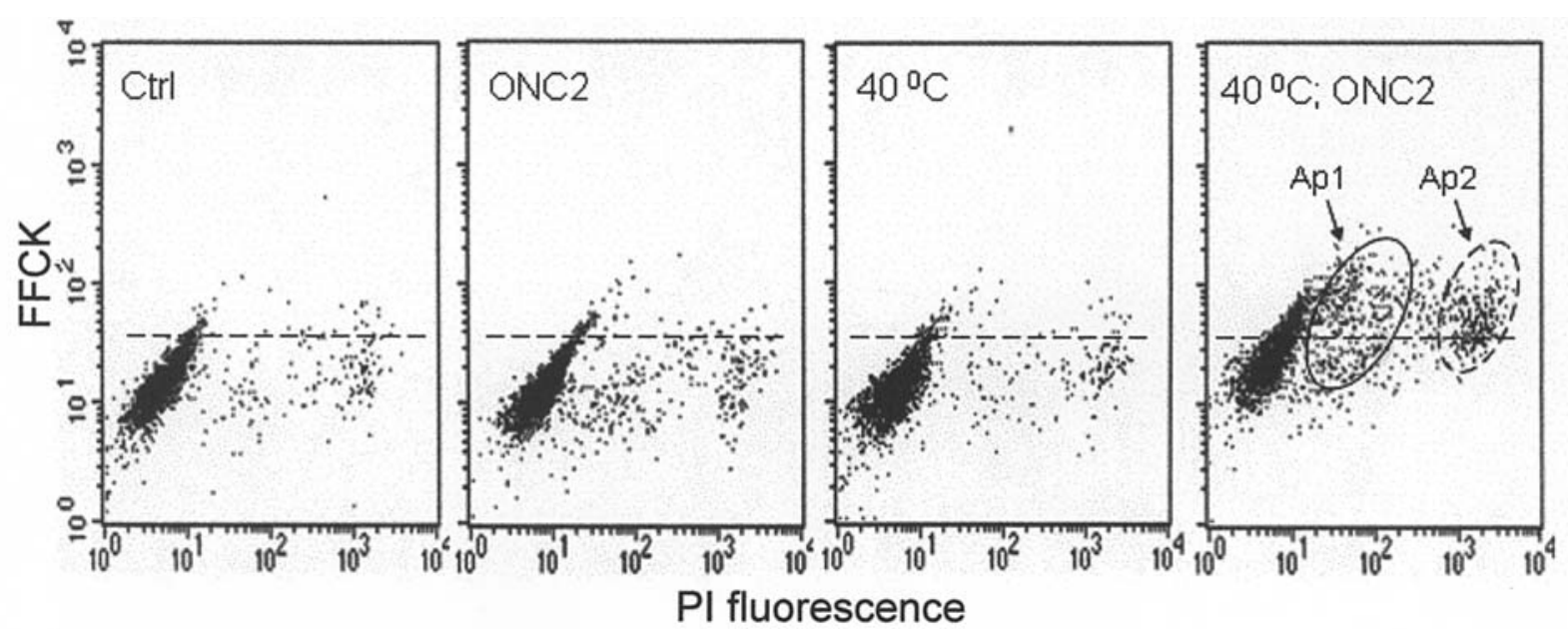

Figure 6. Activation of serine proteases in TK6 cells induced to apoptosis by treatment with ONC and hyperthermia. Bivariate distributions displaying intensity of propidium iodide (PI) fluorescence vs. fluorescence of FFCK, the carboxyfluorescein-tagged inhibitor-ligand of active center of chymotrypsinlike serine proteases $(41,42)$. The cells were growing at $37.5^{\circ} \mathrm{C}(\mathrm{Ctrl})$, treated with $2 \mu \mathrm{g} / \mathrm{ml}$ of $\mathrm{ONC}$ at $37.5^{\circ} \mathrm{C}$ for $24 \mathrm{~h}(\mathrm{ONC} 2)$, growing at $40^{\circ} \mathrm{C}$ for $24 \mathrm{~h}$ $\left(40^{\circ} \mathrm{C}\right)$, or treated with $2 \mu \mathrm{g} / \mathrm{ml}$ of $\mathrm{ONC}$ at $40^{\circ} \mathrm{C}$ for $24 \mathrm{~h}\left(40^{\circ} \mathrm{C}\right.$; ONC2), respectively. The increased PI fluorescence reports increasing permeability of plasma membrane to this fluorochrome and allows one to distinguish early- (Ap1) and late- (Ap2) apoptotic cells (44). The maximal level of FFCK binding below which $>97 \%$ of cells in the untreated $37.5^{\circ} \mathrm{C}$ culture $(\mathrm{Ctrl})$ were located in the scatterplot is marked in each panel with dashed line. The increased FFCK binding, particularly of Ap2 cell population indicates activation of serine proteases $(41,42)$.

of active enzymatic center of chymotrypsin-like proteases $(41,42,45)$. The elevated FFCK fluorescence reports binding of this probe to the enzymatic center of proteases and thereby their activation $(21,41,42)$. Concurrently, integrity of cellular plasma membrane was probed by a brief exposure of cells to PI. This cationic fluorochrome is normally excluded from live cells, to a large degree is excluded also from cells at early stage of apoptosis, but it easily penetrates plasma membrane and strongly labels cells with compromised plasma membrane integrity such as cells at late stage of apoptosis or dying by necrosis (46). As shown in Fig. 6 the assay was able to identify live vs. apoptotic cells and among the latter to distinguish early- (Ap1) vs. late- (Ap2) apoptotic cells. The data are consistent with the morphological observations (Fig. 1), and with the findings based on detection of activated caspase- 3 (Figs. 2 and 3), that cell growth at $40^{\circ} \mathrm{C}$ had no effect on their viability while treatment with $\mathrm{ONC}$ at $40^{\circ} \mathrm{C}$ induced distinctly higher frequency of apoptotic cells than treatment with ONC at $37^{\circ} \mathrm{C}$. Compared with live cells (Ctrl) apoptotic cells, particularly at later phase of apoptosis (Ap2) had a higher level of FFCK fluorescence, indicative of activation of serine protease(s) in these cells $(21,41,42)$.

\section{Discussion}

The presented data indicate that induction of apoptosis of TK6 cells by ONC was enhanced under conditions of mild hyperthermia. Apoptosis was manifested by classical changes in cell morphology and activation of caspase-3 (Figs. 1 and 2), both considered the hallmarks of apoptotic mode of cell death (46). The presence of activated serine protease(s) was also apparent (Fig. 5), consistent with the earlier study that ONC-induced apoptosis triggers activation of these proteases as well (21).

Particularly interesting are findings showing increased incidence of apoptosis in cultures treated with $\mathrm{ONC}$ at $40^{\circ} \mathrm{C}$, i.e. at the temperature at which, in the absence of $\mathrm{ONC}$, the cells were totally unaffected. Namely, we were unable to see any significant effect of $40^{\circ} \mathrm{C}$-hyperthermia alone, not only on incidence of apoptosis of TK6 cells (Figs. 1-3), but also on their progression through the cell cycle (data not shown). The data, thus, are encouraging in terms that they suggest that the antitumor effectiveness of ONC may be increased under conditions of very mild hyperthermia that can be tolerated by the patient. The whole-body hyperthermia at $40^{\circ} \mathrm{C}$, or even at $41^{\circ} \mathrm{C}$, is considered to be a safe therapy that does not lead to any serious or sustained organ dysfunction (47).

As mentioned in the Introduction, hyperthermia increases the therapeutic response and often is synergistic with cytotoxic drugs or radiation (31-38). The possibilities of a combination of hyperthermia with other antitumor modalities are expanding, and are being driven by the development of new approaches providing improved control of thermal delivery to the tumor, such as mediated by cancer imaging and nanoparticles of gold or magnetite (48-50). Since ONC is already in clinical trials where it shows therapeutic activity against malignant mesothelioma $(5,19)$, it could be expected that its effectiveness may still be improved by combination with hyperthermia. Experiments are currently in progress on the effect of mild hyperthermia in combination with ONC on mesothelioma cells and comparing it with normal, non-tumor cells of different lineage in vitro.

The mechanism that may be responsible for the observed enhancement of cytotoxic activity of ONC under conditions of mild hyperthermia is unknown. As mentioned, ONC is taken up by the cells by the endocytic pathway $(14,23,24)$ and as an active ribonuclease is enzymatically targeting intracellular RNA $(14,28)$. It is thus possible that hyperthermia accelerates the endocytic process of ONC internalization and thereby its effectiveness. It is also possible that the enzymatic activity of ONC in terms of a rate of RNA digestion within the target cells, such as kinetics of other enzymes, is accelerated at higher temperature and this contributes to its enhanced cytotoxic activity. Of course, both mechanisms may play a role concurrently. 
We have previously postulated that the mechanism of ONC antitumor action may involve targeting RNAi (29). The actual direct target may be microRNAs (miRNAs), whose destruction could activate translation of particular genes otherwise silenced by these mRNAs. The observed upregulation of some gene products such as CKIs by ONC would be consistent with this mechanism (20). Also consistent with this mechanism are our recent findings on up- and down-regulation by ONC of specific sets of genes in mesothelioma cell lines (unpublished data). In addition, it is conceivably that ONC may mimic activity of Dicer, a member of the RNase III enzyme family, by cleaving large transcripts and generating miRNAs with gene silencing properties (51).

The targeting RNAi may be the mechanism responsible for higher effectiveness of ONC towards tumor as compared to normal cells. It was recently shown that development of many tumors is associated with early alterations at the level of miRNA genes (52-57). These genes are often located at the genome hot spots associated with cancer. There is a growing body of evidence that miRNAs are extensively involved in pathogenesis not only of leukemias or lymphomas but also of solid tumors and they promote neoplastic growth by controlling the expression of protein-coding tumor suppressors and oncogenes (56). Thus, by targeting RNAi, ONC may be more effective in suppressing growth of tumor than normal cells.

Is there any evidence that ONC may target RNAi in frog eggs or developing embryos and could this be its physiological function? Unfortunately, little is known about the possible role of ONC of embryo development or its targets within an egg or embryo. It has been proposed that ribonucleases of RNase A superfamily having anti-pathogen activities may be involved in innate host defense (58). Within the framework of this function microbial RNA would be their primary target. However, RNAi plays a critical role in gene regulation during development (59-63). Abundance of ONC in developing embryo is clearly consistent with its possible role in RNAi-mediated gene regulation during embryogenesis.

RNases homologous to ONC are present in eggs of a variety of amphibian species (5). It is intriguing to note that the sex of amphibians is determined by the characteristic temperature at which the egg is incubated (64-66). The mechanism of sex determination appears to depend on the modulation of expression of particular genes, which varies at the temperatures favoring either males or females (66). Our present data indicate that effects of ONC are temperaturedependent and one of the possible mechanisms for the observed effect is the variation in ONC enzyme kinetics with temperature. Therefore, we speculate that if ONC or its homologues play a role in gene regulation via RNAi mechanism, the sex determining genes are among the regulated genes.

\section{Acknowledgements}

This study was supported in part by NCI CA 28704.

\section{References}

1. Ardelt W, Mikulski SM and Shogen K: Amino acid sequence of an anti-tumor protein from Rana pipiens oocytes and early embryos. Homology to pancreatic ribonuclease. J Biol Chem 266: 245-251, 1991 .
2. Ardelt W, Lee HS, Randolph G, Viera A, Mikulski SM and Shogen K: Enzymatic characterization of onconase, a novel ribonuclease with anti-tumor activity. Protein Sci 3 (Suppl 1): 137-147, 1994.

3. Mosimann SC, Ardelt W and James MNG: Refined $1.7 \mathrm{~A}^{\circ} \mathrm{X}$-ray crystallographic structure of $\mathrm{P}-30$ protein, an amphibian ribonuclease with antitumor activity. J Mol Biol 236: 1141-1153, 1994.

4. Pavlakis $\mathrm{N}$ and Vogelzang NJ: Ranpirnase - an antitumor ribonuclease: its potential role in malignant mesothelioma. Expert Opin Biol Ther 6: 1391-1399, 2006.

5. Irie $M$, Nitta $K$ and Nonaka T: Biochemistry of frog ribonucleases. Cell Mol Life Sci 54: 775-784, 1998.

6. Leland PA and Raines RT: Cancer chemotherapy - ribonucleases to the rescue. Chem Biol 8: 405-413, 2001.

7. Arnold U and Ulbrich-Hofmann R: Natural and engineered ribonucleases as potential cancer therapeutics. Biotechnol Lett 28: 1615-1622, 2006.

8. Benito A, Ribo M and Vilanova M: On the track of antitumor ribonucleases. Mol BioSyst 1: 294-302, 2005.

9. Darzynkiewicz Z, Carter SP, Mikulski SM, Ardelt WJ and Shogen K: Cytostatic and cytotoxic effects of Pannon (P-30 Protein), a novel anticancer agent. Cell Tissue Kinetics 21: 169-182, 1988.

10. Boix E, Wu Y-N, Vasandani VM, Saxena SK, Ardelt W, Ladner J and Youle RJ: Role of $\mathrm{N}$ terminus in RNase A homologues: Differences in catalytic activity, ribonuclease inhibitor interaction and cytotoxicity. J Mol Biol 257: 992-1007, 1996.

11. Mikulski S, Viera A, Darzynkiewicz Z and Shogen K: Synergism between a novel amphibian oocyte ribonuclease and lovastatin in inducing cytostatic and cytotoxic effects in human lung and pancreatic carcinoma cell lines. Br J Cancer 66: 304-310, 1992.

12. Mikulski S, Viera A and Shogen K: In vitro synergism between a novel amphibian oocytic ribonuclease (ONCONASE) and tamoxifen, lovastatin and cisplatin in human OVCAR-3 ovarian carcinoma cell line. Int J Oncol 1: 779-785, 1992

13. Rybak SM, Pearson J, Fogler W, Volker K, Spence S, Newton DL, Mikulski SM, Ardelt W, Riggs C, Kung H and Longo D: Enhancement of vincristine cytotoxicity in drugresistant cells by simultaneous treatment with ONCONASE, an antitumor ribonuclease. J Natl Cancer Inst 88: 747-753, 1996.

14. Wu Y, Mikulski SM, Ardelt W, Rybak SM and Youle RJ: A cytotoxic ribonuclease. Study of the mechanism of onconase cytotoxicity. J Biol Chem 268: 10686-10693, 1993.

15. Mikulski SM, Bernstein E, Ardelt W, Shogen K and Menduke K: Striking increase in survival of mice bearing M109 Madison carcinoma treated with a novel protein from amphibian embryos. J Natl Cancer Inst 82: 151-153, 1990.

16. Deptala A, Halicka HD, Ardelt W, Mikulski SM, Shogen K and Darzynkiewicz Z: Potentiation of tumor necrosis factor induced apoptosis by onconase. Int J Oncol 13: 11-16, 1998.

17. Mikulski S, Viera A, Ardelt W, Menduke H and Shogen K: Tamoxifen and trifluoroperazine (Stelazine) potentiate cytotostatic/cytotoxic effects of P-30 Protein, a novel protein possesing anti-tumor activity. Cell Tissue Kinet 32: 237-246, 1990.

18. Mikulski SM, Viera A, Deptala A and Darzynkiewicz Z: Enhanced in vitro cytotoxicity and cytostasis of the combination of onconase with a proteasome inhibitor. Int J Oncol 13: 633-644, 1998

19. Mikulski SM, Constanzi JJ, Vogelzang NJ, McCachren S, Taub RN, Chun H, Mittelman A, Panella T, Puccio C, Fine R and Shogen K: Phase II trial of a single weekly intravenous dose of ranpirnase in patients with unresectable malignant mesothelioma. J Clin Oncol 20: 274-281, 2002.

20. Juan G, Ardelt B, Li X, Mikulski SM, Shogen K, Ardelt W, Mittelman A and Darzynkiewicz Z: G1 arrest of U-937 cells by onconase is associated with suppression of cyclin D3 expression, induction of $\mathrm{p} 16^{\mathrm{INK} 4 \mathrm{~A}}, \mathrm{p} 21^{\mathrm{WAF} 1 \mathrm{CIP} 1}$ and $\mathrm{p} 27^{\mathrm{KIP}}$ and decreased $\mathrm{pRb}$ phosphorylation. Leukemia 12: 1241-1248, 1998.

21. Grabarek J, Ardelt B, Du L and Darzynkiewicz Z: Activation of caspases and serine proteases during apoptosis induced by onconase (Ranpirnase). Exp Cell Res 278: 61-71, 2002.

22. Halicka HD, Murakami T, Papageorgio CN, Mittelman A, Mikulski SM, Shogen K and Darzynkiewicz Z: Induction of differentiation of leukemic (HL-60) or prostate cancer (LNCaP, JCA-1) cells potentiates frequency of apoptosis triggered by onconase. Cell Prolif 33: 407-417, 2000. 
23. Wu Y, Saxena SK, Ardelt W, Gadina M, Mikulski SM, De Lorenzo C, D'Alessio G and Youle RJ: A study of the intracellular routing of cytotoxic ribonucleases. J Biol Chem 270: 17476-17481, 1996.

24. Haigis MC and Raines RT: Secretory ribonucleases are internalized by a dynamin-independent endocytic pathway. J Cell Sci 116: 313-324, 2003

25. Iordanov MS, Ryabinina OP, Wong J, Dinh TH, Newton DL, Rybak SM and Magun BE: Molecular determinants of apoptosis induced by the cytotoxic ribonuclease onconase: evidence for cytotoxic mechanisms different from inhibition of protein synthesis. Cancer Res 60: 1983-1994, 2000.

26. Saxena SK, Sirdeshmukh R, Ardelt W, Mikulski SM, Shogen K and Youle RJ: Entry into cells and selective degradation of tRNA by a cytotoxic member of the RNase A family. J Biol Chem 277: 15142-15146, 2002.

27. Traganos F, Kimmel M, Bueti C and Darzynkiewicz Z: Effects of inhibition of RNA or protein synthesis on CHO cell cycle progression. J Cell Physiol 133: 277-287, 1987.

28. Gong J, Li X and Darzynkiewicz Z: Different patterns of apoptosis of HL-60 cells induced by cycloheximide and camptothecin. J Cell Physiol 157: 263-270, 1993.

29. Ardelt B, Ardelt W and Darzynkiewicz Z: Cytotoxic ribonucleases and RNA interference (RNAi). Cell Cycle 2: 22-24, 2003.

30. Halicka DH, Pozarowski P, Ita M, Ardelt W, Mikulski SM, Shogen K and Darzynkiewicz Z: Enhancement of activationinduced apoptosis of lymphocytes by the cytotoxic ribonuclease onconase (Ranpirnase). Int J Oncol 21: 1245-1250, 2002.

31. Coffey DS, Getzenberd RH and De Weese TL: Hyperthermic biology and cancer therapies. A hypothesis for the 'Lance Armstrong effect'. JAMA 296: 445-448, 2006.

32. Takahashi I, Emi Y, Hasuda S, Kakeji Y, Maehara Y and Sugimachi K: Clinical application of hyperthermia combined with anticancer drugs for the treatment of solid tumors. Surgery 131 (Suppl 1): S78-S84, 2002

33. Nakao K, Otsuki Y, Akao Y, Ito Y, Marukawa O, Tachibana S, Kawakami M and Sasaki S: The synergistic effects of hyperthermia and anticancer drugs on induction of apoptosis. Med Electron Microsc 33: 44-50, 2000.

34. Ryu S, Brown SL, Sang-Hie K, Khil MS and Jae Ho H: Preferential radiosensittization of human prostatic carcinoma cells by mild hyperthermia. Int J Radiat Oncol Biol Phys 34: 133-138, 1996.

35. Takahashi T, Mitsuhashi N, Sakurai H, Murata O Kitamoto Y, Matsumoto H, Higuchi $\mathrm{K}$ and Niibe $\mathrm{H}$ : Thermal enhancement of pirarubicin (THP-adriamycin) by mild hyperthermia in vitro. Int J Hyperther 13: 317-324, 1997.

36. Herman TS, Teicher BA and Holden SA: Trimodality therapy (drug/hyperthermia/radiation) with BCNU or mitomycin C. Int J Radiat Oncol Biol Phys 18: 375-382, 1990.

37. Takemoto M, Kuroda M, Urano M, Nishimura Y, Kawasaki S, Kato H, Okumara Y, Akaki S, Kanazawa S, Asaumi J, Joja I and Hiraki Y: The effect of various chemotherapeutic agents given with mild hyperthermia on different types of tumors. Int $\mathbf{J}$ Hyperther 19: 193-203, 2003.

38. Blasiak J, Widera K and Pertynski T: Hyperthermia can differentially modulate the repair of doxorubicin-damaged DNA in normal and cancer cells. Acta Biochim Pol 50: 191-195, 2003.

39. Schwartz JL, Jordan E, Evans HH, Lenarczyk M and Liber H: The TP53 dependence of radiation-induced chromosome instability in human lymphoblastoid lines. Radiat Res 159: 730-736, 2003

40. Tanaka T, Kurose A, Huang X, Traganos F, Dai W and Darzynkiewicz Z: Extent of constitutive histone H2AX phosphorylation on Ser-139 varies in cells with different TP53 status. Cell Prolif 39: 313-323, 2006

41. Grabarek J, Dragan M, Lee BW, Johnson GL and Darzynkiewicz Z: Activation of chymotrypsin-like serine protease(s) during apoptosis detected by affinity-labeling of the enzymatic center with the fluoresceinated inhibitor. Int J Oncol 20: 225-233, 2002.

42. Grabarek J, Du L, Johnson GL, Lee B, Phelps DJ and Darzynkiewicz Z: Sequential activation of caspases and serine proteases (serpases) during apoptosis. Cell Cycle 1: 124-131, 2002.

43. Huang X, Halicka HD, Traganos F, Tanaka T, Kurose A and Darzynkiewicz Z: Cytometric assessment of DNA damage in relation to cell cycle phase and apoptosis. Cell Prolif 38: 223-243, 2005.
44. Huang X, Kurose A, Tanaka T, Traganos F, Dai W and Darzynkiewicz Z: Activation of ATM and histone H2AX phosphorylation induced by mitoxantrone but not by topotecan is prevented by the antioxidant $\mathrm{N}$-acetyl-L-cysteine. Cancer Biol Ther 5: 959-964, 2006.

45. Darzynkiewicz Z and Barnard EA: Specific proteases of the rat mast cell. Nature 213: 1198-1202, 1967.

46. Darzynkiewicz Z, Bruno S, Del Bino G, Gorczyca W, Hotz MA, Lassota P and Traganos F: Features of apoptotic cells measured by flow cytometry. Cytometry 13: 795-808, 1992.

47. Kerner T, Deja M, Ahlers O, Loffel J, Hildebrand B, Wust P, Gerlach $\mathrm{H}$ and Riss $\mathrm{H}$ : Whole body hyperthermia: a secure procedure for patients with various malignancies. Intensive Care Med 25: 959-965, 1999 .

48. Ito A, Honda $\mathrm{H}$ and Kobayashi T: Cancer immunotherapy based on intracellular hyperthermia using magnetite nanoparticles: a novel concept of 'heat-controlled necrosis' with heat shock protein expression. Cancer Immunol Immunother 55: 320-328, 2006.

49. Huang X, El-Sayed IH, Qian W and El-Sayed MA: Cancer imaging and photothermal therapy in the near-infrared region by using gold nanorods. J Am Chem Soc 128: 2115-2120, 2006.

50. Milne PJ, Parel JM, Manns F, Denham DB, Gonzalez-Cirre X and Robinson DS: Development of stereotactically guided laser interstinal thermotherapy of breast cancer: in situ measurement and analysis of the temperature field in ex vivo and in vivo adipose tissue. Lasers Surg Med 26: 67-75, 2000.

51. Zhang H, Kolb FA, Jaskiewicz L, Westhof E and Filipowicz W: Single processing center models for human Dicer and bacterial RNase III. Cell 118: 57-68, 2004.

52. Calin GA and Croce CM: Genomics of chronic lymphocytic leukemia microRNAs as new players with clinical significance. Semin Oncol 33: 163-173, 2006.

53. Iorio MV, Ferracin M, Liu CG, Veronese A, Spizzo R, Sabbioni S, Magr E, Pedriali M, Fabrbri M, Campiglio M, Menard S, Palazzo JP, Rosenberg A, Musiani P, Volinia S, Nenci I, Calin GA, Querzoli P, Negrini M and Croce CM: MicroRNA gene expression deregulation in human breast cancer. Cancer Res 65: 7065-7070, 2005 .

54. Calin GA and Croce CM: MicroRNAs and chromosomal abnormalities in cancer cells. Oncogene 25: 6202-6210, 2006.

55. Sevignani C, Calin GA, Siracusa LD and Croce CM: Mammalian microRNAs: a small world for fine-tuning gene expression. Mamm Genome 17: 189-202, 2006.

56. Volinia S, Calin GA, Liu C-G, Ambs S, Cimmino A, Petrocca F, Visone R, Iorio M, Roldo C, Ferracin M, Prueitt RL, Yunaihara N, Lanza G, Scarpa A, Veccione A, Negrini M, Harris CC and Croce CM: A microRNAs expression signature of human solid tumors defines cancer gene targets. Proc Natl Acad Sci USA 103: 2257-2261, 2006.

57. Chan JA, Krichevsky AM and Kosik KS: MicroRNA-21 is an antiapoptotic factor in human glioblastoma cells. Cancer Res 65: 6029-6033, 2005.

58. Dyer KD and Rosenberg HF: The RNase A superfamily: generation of diversity and innate host defense. Mol Divers 10: 585-597, 2006.

59. Mattick JS: RNA regulation: a new genetics. Nat Rev Genet 5: 316-323, 2004.

60. Banerjee D and Slack F: Control of developmental timing by small temporal RNAs: a paradigm for RNA-mediated regulation of gene expression. Bioessays 24: 19-29, 2002.

61. Mishima Y, Giraldez AJ, Takeda Y, Fujiwara T, Sakamoto H, Schier AF and Inoue K: Differential regulation of germline mRNAs in soma and germ cells by zebrafish miR-430. Curr Biol 16: 2135-2142, 2006.

62. Song L and Tuan RS: MicroRNAs and cell differentiation in mammalian development. Birth Defects Res C Embryo Today 78: 140-149, 2006.

63. Yang WJ, Yang DD, Na S, Sandusky GE, Zhang Q and Zhao G: Dicer is required for embryonic angiogenesis during mouse development. J Biol Chem 280: 9330-9335, 2005.

64. Ferguson MW and Joanen T: Temperature of egg incubation determining sex in alligator mississipiensis. Nature 296: 850-853, 1982.

65. Eggert C: Sex determination: the amphibian models. Reprod Nutr Dev 44: 539-549, 2004.

66. Sakata N, Miyazaki K and Wakahara M: Up-regulation of P450arom and down-regulation of Dmrt-1 genes in the temperature-dependent sex reversal from genetic males to phenotypic females in salamander. Dev Genes Evol 216: 224-228, 2006 . 